CADEMARTORI, Daniela Mesquita Leutchuk de; CAMPOS, Luciana Oliveira. Democracia e participação social efetiva: confrontação agonística como instrumento de legitimação dos atos das Agências Reguladoras brasileiras. Revista Eletrônica Direito e Política, Programa de Pós-Graduação Stricto Sensu em Ciência Jurídica da UNIVALI, Itajaí, v.13, n.3, $3^{\circ}$ quadrimestre de 2018. Disponível em: www.univali.br/direitoepolitica - ISSN 1980-7791

\title{
DEMOCRACIA E PARTICIPAÇÃO SOCIAL EFETIVA: CONFRONTAÇÃO AGONÍSTICA COMO INSTRUMENTO DE LEGITIMAÇÃO DOS ATOS DAS AGÊNCIAS REGULADORAS BRASILEIRAS
}

\author{
DEMOCRACY AND EFFECTIVE SOCIAL PARTICIPATION: AGONISTIC \\ CONFRONTATION AS NA INSTRUMENT TO LEGITIMIZE ACTS OF BRAZILIAN \\ REGULATORY AGENCIES
}

Daniela Mesquita Leutchuk de Cademartori ${ }^{1}$

Luciana Oliveira de Campos²

\begin{abstract}
SUMÁRIO: Introdução; 1 A reforma do Estado brasileiro segundo o modelo norteamericano; 2 Legitimação dos atos das Agências Reguladoras: a necessária participação social agonística como instrumento de superação do déficit democrático; 3 A necessária confrontação agonística nos processos de Audiências e Consultas Públicas promovidos pelas Agências Reguladoras; Considerações finais; Referências das fontes citadas.
\end{abstract}

\section{RESUMO}

No presente trabalho procura-se analisar a importância da confrontação agonística nos processos de participação social promovidos pelas Agências Reguladoras brasileiras, constituídas como entidades especializadas e autônomas - seguindo modelo neoliberal de regulação de serviços públicos e algumas atividades econômicas - que carregam consigo um problema de legitimidade e desconformidade com o princípio democrático, notadamente por serem imunes às interferências políticas. Trabalha-se tendo como mote o princípio democrático consagrado na Constituição e a necessidade de promoção de participação social efetiva na construção de decisões legitimas, adotando como aportes teóricos a sociologia de Pierre Bourdieu, especialmente no que tange as suas críticas a mundialização das ideias neoliberais, associado ao ideal de democracia radical apresentado por Chantal Mouffe como um modelo democrático "capaz de criar formas de poder mais compatíveis com valores democráticos", colocando o conflito a ser trabalhado de forma agonística como elemento central.

Palavras-chave: agências reguladoras; confrontação agonística; democracia; legitimidade.

1 Mestre e Doutora em Direito pela UFSC. Professora do Programa de Pós-Graduação e da Graduação em Direito da Unilasalle (Canoas-RS). Coordenadora do Projeto Em Busca de Novas Gramáticas para os Direitos Humanos: inovações sócio-jurídicas-políticas entre América Latina e África (Universal MCTI/CNPq n. 1/2016) no qual se insere este trabalho. E-MAIL: daniela.cademartori@unilasalle.edu.br

2 Advogada. Mestra em Direito e Sociedade pela Universidade La Salle-Canoas/RS. E-MAIL: luciana47853@gmail.com 
CADEMARTORI, Daniela Mesquita Leutchuk de; CAMPOS, Luciana Oliveira. Democracia e participação social efetiva: confrontação agonística como instrumento de legitimação dos atos das Agências Reguladoras brasileiras. Revista Eletrônica Direito e Política, Programa de Pós-Graduação Stricto Sensu em Ciência Jurídica da UNIVALI, Itajaí, v.13, n.3, $3^{\circ}$ quadrimestre de 2018. Disponível em: www.univali.br/direitoepolitica - ISSN 1980-7791

\section{ABSTRACT}

In the present work, we seek to analyze the importance of the agonistic confrontation in the processes of social participation promoted by the brazilian Regulatory Agencies, constituted as specialized and autonomous entities following a neoliberal model of regulation of public services and some economic activities - that carry with them a problem of legitimacy and non-conformity with the democratic principle, notably because they are immune to political interference. It works with the democratic principle enshrined in the Constitution and the need to promote effective social participation in the construction of legitimate decisions, adopting as theoretical contributions the sociology of Pierre Bourdieu, especially as regards its criticism of the globalization of neoliberal ideas, associated with the ideal of radical democracy presented by Chantal Mouffe as a democratic model "capable of creating forms of power more compatible with democratic values", placing the conflict to be worked agonistically as a central element.

Keywords: regulatory agencies; agonistic confrontation; democracy; legitimacy.

\section{INTRODUÇÃO}

Desde meados dos anos noventa inúmeros serviços públicos e atividades econômicas essenciais ao desenvolvimento social e econômico do Brasil passaram a ser reguladas por entidades denominadas Agências, responsáveis pela normatização e fiscalização do efetivo exercício das atividades reguladas. Seguindo modelo norte-americano por meio de reforma econômica que teve como objetivo a redução da interferência direta do Estado em determinados setores, foram privatizadas empresas públicas e criadas autarquias especiais denominadas agências reguladoras.

A referida reforma ocorreu em um momento em que o Estado brasileiro vivenciava uma crise financeira profunda, que o expôs a pressões externas promovidas por instituições internacionais, tais como o Banco Mundial e o Fundo Monetário Internacional, os quais exigiam não só a redução da interferência do Estado pretendiam assegurar-se de que a essa nova ordem das coisas não seria alterada no futuro de forma abrupta. Essa segurança de manutenção da ordem deveria ser afiançada por meio da criação de entidades detentoras de singular autonomia, poder normativo e de fiscalização.

Tais entidades especiais, denominadas Agências Reguladoras, foram constituídas de forma muito peculiar e dotadas de poder regulamentar fixado por leis, que nada 
CADEMARTORI, Daniela Mesquita Leutchuk de; CAMPOS, Luciana Oliveira. Democracia e participação social efetiva: confrontação agonística como instrumento de legitimação dos atos das Agências Reguladoras brasileiras. Revista Eletrônica Direito e Política, Programa de Pós-Graduação Stricto Sensu em Ciência Jurídica da UNIVALI, Itajaí, v.13, n.3, $3^{\circ}$ quadrimestre de 2018. Disponível em: www.univali.br/direitoepolitica - ISSN 1980-7791

mais estabelecem do que standards, delineados por diretrizes e políticas públicas a serem observadas e efetivadas. A independência ou autonomia que possuem em face ao Poder Público é assegurada por medidas como orçamento próprio, a administração e direção atribuída a um colegiado composto por membros que possuem perfil técnico, nomeados para mandato por prazo determinado e não destituíveis ad nutum, o que Ihes confere uma espécie de estabilidade provisória.

Algumas características que asseguram autonomia às agências fazem recair sobre estas um problema de legitimidade advindo do déficit democrático em sua gestão, eis que não estão sujeitas à interferência daqueles chefes de governo eleitos por meio do voto. A cidadania, princípio constitucional fundamental, intimamente ligado à democracia, assegura aos cidadãos o direito de participar da vida política do Estado, impondo ao Estado o incentivo a efetiva participação. Assim, para que as atividades de regulação e fiscalização dos serviços públicos sejam percebidas como legítimas é essencial a mobilização e construção de mecanismos que levem a sociedade a participar de forma ativa nas decisões das Agências Reguladoras e para isso a democracia pluralista cumpre um importante papel.

Por meio do presente estudo, que não tem a pretensão de esgotar a matéria, buscar-se-á analisar o problema da legitimidade dos atos administrativos das Agências Reguladoras decorrente de déficit democrático e o processo de participação como instrumento de legitimação em uma sociedade plural, o qual deverá possibilitar uma confrontação agonística e assim sanar possível problema decorrente da ausência de interferência política em sua gestão.

Visando provocar a reflexão sobre a problemática do déficit democrático que afeta a legitimidade dos atos das agências reguladoras brasileiras e a utilização de um processo de participação social efetivo como instrumento de legitimação o presente trabalho foi elaborado em três partes. Inicialmente tratar-se-á sobre a constituição das Agências Reguladoras no Brasil notadamente no que tange ao modelo adotado e as principais características que asseguram a estas uma autonomia reforçada no exercício de suas atribuições; na sequência discorrer-seá sobre a questão pontual do déficit democrático perante algumas contribuições encontradas na doutrina que adota o pluralismo agonístico como modelo de 
CADEMARTORI, Daniela Mesquita Leutchuk de; CAMPOS, Luciana Oliveira. Democracia e participação social efetiva: confrontação agonística como instrumento de legitimação dos atos das Agências Reguladoras brasileiras. Revista Eletrônica Direito e Política, Programa de Pós-Graduação Stricto Sensu em Ciência Jurídica da UNIVALI, Itajaí, v.13, n.3, $3^{\circ}$ quadrimestre de 2018. Disponível em: www.univali.br/direitoepolitica - ISSN 1980-7791

democracia; e por fim discorrer-se-á sobre o instrumento de participação social intitulado de audiência pública, sob a ótica do pluralismo e o modelo de confrontação agonística, aventando a possibilidade de ser este um instrumento de construção da legitimidade dos atos das Agências Reguladoras.

No presente estudo serão adotadas como referencial teórico algumas noções da sociologia de Pierre Bourdieu, o qual, por meio de sua obra, lança importantes críticas à mundialização e os efeitos nefastos das medidas impostas por instituições internacionais sobre países periféricos procurando alinhar com o "pluralismo agonístico", modelo de democracia advogado por Chantal Mouffe a qual defende a necessidade de um modelo democrático que seja "capaz de construir formas de poder mais compatíveis com valores democráticos", contexto no qual, o poder e o antagonismo são questões centrais. ${ }^{3}$

Além dos aportes do sociólogo francês e da cientista política belga, a pesquisa incluirá conceitos de outros estudiosos do tema da democracia e da legitimidade dos atos administrativos, bem como bibliografia secundária acerca das peculiaridades da constituição das agências e sobre algumas de suas atribuições.

\section{A REFORMA DO ESTADO BRASILEIRO SEGUNDO O MODELO NORTE- AMERICANO}

As ideias de reforma do Estado voltadas a promover uma maior liberdade para o mercado e a consequente redução da atuação do Estado tiveram início e se propagaram a partir dos anos oitenta nos Estados Unidos da América na época sob o governo de Ronald Reagan, bem como na Inglaterra comandada pela primeira ministra Margareth Thatcher. As medidas adotadas nesse processo de reforma de

\footnotetext{
3 MOUFFE, Chantal. Democracia, cidadania e a questão do pluralismo. Tradução de K. Prudencio. Política \& Sociedade. UFSC, Florianópolis, v. 2, no 3, p. 17, 2003. Disponível em: <https://periodicos.ufsc.br/index.php/politica/article/view/2015>. Acesso em: 21 Set. 2018. e Por um modelo agonístico de democracia. Tradução de P. S. Ghetti. Revista de Sociologia Política. UFPR, Curitiba, n. 5, p. 19, nov. 2005. Disponível em: <http://www.scielo.br/pdf/rsocp/n25/31108.pdf>. Acesso em: 21 set. 2018.
} 
CADEMARTORI, Daniela Mesquita Leutchuk de; CAMPOS, Luciana Oliveira. Democracia e participação social efetiva: confrontação agonística como instrumento de legitimação dos atos das Agências Reguladoras brasileiras. Revista Eletrônica Direito e Política, Programa de Pós-Graduação Stricto Sensu em Ciência Jurídica da UNIVALI, Itajaí, v.13, n.3, $3^{\circ}$ quadrimestre de 2018. Disponível em: www.univali.br/direitoepolitica - ISSN 1980-7791

transformação do Estado provedor em um estado meramente gestor levaram a desestatizações e privatizações. ${ }^{4}$

Durante o período de mundialização das ideias neoliberais - último quartel do século XX - fundadas na defesa de uma menor intervenção dos Estados, o Brasil se encontrava sob severa crise fiscal e uma consequente instabilidade cujas repercussões eram sentidas interna e externamente, perpassando pela alta de juros, bem como elevação da inflação, culminando com o agravamento da dívida externa, colocando o País em uma situação difícil perante entidades como o Banco Mundial e o Fundo Monetário Internacional. ${ }^{5}$

A incapacidade do país de atender às demandas sociais internas despertou o descontentamento de trabalhadores e intelectuais, que passaram a protestar por maior participação nas decisões do governo, ao mesmo tempo em que os empresários culpavam a máquina estatal pela crise, cobrando desoneração mediante privatização. ${ }^{6}$ Enquanto isso, externamente organismos internacionais pressionavam e exigiam reformas como condição para concessão de novos empréstimos. Exigências impostas a países como o Brasil podem ser observadas no relatório do Banco Mundial no qual é destacada a condição imposta de reforma no setor elétrico:

Uma exigência para qualquer empréstimo no setor elétrico será um movimento explícito do país rumo ao estabelecimento de um quadro jurídico e processos regulatórios satisfatórios para o Banco. Para esse fim, em conjunção com outras iniciativas de âmbito econômico, o Banco exigirá dos países que estabeleçam processos regulatórios transparentes que sejam claramente

4 GUIMARÃES, Lucas Noura de Moraes. Regulação da exploração da eletricidade: compatibilidade com as leis da natureza e com a ordem econômica constitucional. Curitiba: CRV, 2013, p. 175.

5 Ver: MOTTA, Paulo Roberto Ferreira. Agências reguladoras. Barueri: Manole, 2003 e SCHNEIDER, Yuri. Agências reguladoras e democracia: a necessária aplicação do modelo de democracia cooperativa reflexiva do conhecimento para legitimação de sua atuação. 2013, $250 f$. Tese (Doutorado em Direito). Programa de Pós-Graduação em Direito. Universidade do Vale do Rio dos Sinos. São Leopoldo, $2013 . \quad$ Disponível em: <http://www.repositorio.jesuita.org.br/bitstream/handle/UNISINOS/4227/Yuri+Schneider.pdf;jses sionid=EFE31497861AB0BE644A7F7CFFD1B896? sequence=1>. Acesso em: 23 set. 2018.

${ }^{6}$ AGUILLAR, Fernando Herren. Controle social de serviços públicos. São Paulo: Max Limonad, 1999. 
CADEMARTORI, Daniela Mesquita Leutchuk de; CAMPOS, Luciana Oliveira. Democracia e participação social efetiva: confrontação agonística como instrumento de legitimação dos atos das Agências Reguladoras brasileiras. Revista Eletrônica Direito e Política, Programa de Pós-Graduação Stricto Sensu em Ciência Jurídica da UNIVALI, Itajaí, v.13, n.3, $3^{\circ}$ quadrimestre de 2018. Disponível em: www.univali.br/direitoepolitica - ISSN 1980-7791

independentes dos fornecedores de energia e que evitem interferência governamental nas operações cotidianas da companhia (pouco importando se a empresa é privada ou pública). O papel dual do governo como operador e titular de serviços públicos conduziu o governo a intervenções frequentes nas operações do setor elétrico. Há, portanto, necessariamente de se definir alguma forma de corpo regulatório como parte de um esforço governamental para redefinir os papéis respectivos do governo, concessionário e consumidores. Isso implica uma mudança do tipo monolítico de gestão governamental em direção a sistemas mais descentralizados e baseados no mercado. ${ }^{7}$

A adoção de forma generalizada em um processo de mundialização de um modelo de Estado por todos os países periféricos, em completa desconsideração das peculiaridades de cada um é apontada por Pierre Bourdieu como destruidora sistêmica dos mecanismos de proteção dos cidadãos por parte do estado nacional e das ações coletivas advinda de entidades como os sindicatos e as associações, neste último caso porque os defensores dos trabalhadores atuam de modo a obstaculizar do desenvolvimento livre do mercado. ${ }^{8}$

A forma com que é defendida a adoção de modelos neoliberais em escala mundial como sendo algo inexorável é objeto de crítica e desmistificação por parte de Pierre Bourdieu. Segundo o autor as políticas econômicas possuem um efeito simbólico produzido mediante a invocação da "autoridade da ciência econômica" quando na verdade é a mundialização de um modelo particular, o qual pertence a um determinado país condizente com a sua história singular e a uma "ordem social particular". 9

Segundo o sociólogo francês a promoção da universalização daquilo que é particular se dá por meio do estabelecimento de postulados como inexoráveis, tais como: (i) a autonomia da economia "governada por leis naturais e universais"

\footnotetext{
7 WORLD BANK, 1993 apud AGUILLAR, Fernando Herren. Controle social de serviços públicos. São Paulo: Max Limonad, 1999, p. 233-234.

${ }^{8}$ VERGARA ESTÉVEZ, Jorge. La utopía neoliberal y sus críticos. Utopìa y Praxis Latinoamericana, Venezuela, v. 10, n. 31, p. 37-62, Oct./Dic. 2005, p. 51. Disponível em: <http://www.redalyc.org/pdf/279/27903103.pdf>. Acesso em: 22 set. 2018.

${ }^{9}$ BOURDIEU, Pierre. Contrafogos 2: por um movimento social europeu. Tradução de André Telles. Rio de Janeiro: Jorge Zahar, 2001, p. 29.
} 
CADEMARTORI, Daniela Mesquita Leutchuk de; CAMPOS, Luciana Oliveira. Democracia e participação social efetiva: confrontação agonística como instrumento de legitimação dos atos das Agências Reguladoras brasileiras. Revista Eletrônica Direito e Política, Programa de Pós-Graduação Stricto Sensu em Ciência Jurídica da UNIVALI, Itajaí, v.13, n.3, 30 quadrimestre de 2018. Disponível em: www.univali.br/direitoepolitica - ISSN 1980-7791

sobre a qual o governo não deve interferir; (ii) o mercado é colocado como a forma perfeita para regular as relações de produção e de trocas nas "sociedades democráticas"; (iii) a necessidade de redução de despesas por parte dos Estados, notadamente aquelas de natureza social tidas "ao mesmo tempo como dispendiosos e disfuncionais". ${ }^{10}$ Por meio de sua crítica ele busca descontruir estas "verdades" e comprovar que o modelo neoliberal norte-americano é peculiar ao seu Estado de origem, fundado em suas bases históricas e em suas peculiaridades e não nos postulados sucintamente citados.

Pierre Bourdieu destaca que os Estados Unidos da América é um Estado fraco por tradição, no qual existem avanços científicos importantes e atrasos sociais rigorosos. Um país em que se valoriza a responsabilidade individual e "em nome da tradição liberal de self help" transfere aos indivíduos a responsabilidade por problemas como desemprego, os quais são na verdade problemas de ordem social. ${ }^{11}$ Além disso, o pesquisador aponta como uma peculiaridade deste Estado o culto ao aumento do capital que impregna a sociedade norte-americana, bem como a consagração do "indivíduo e do 'individualismo" tão expressivo que na sua visão compromete até mesmo as ações coletivas identificadas como "agregações de ações individuais isoladas". ${ }^{12}$ (Destaque do autor).

Outra peculiaridade apontada por Pierre Bourdieu ${ }^{13}$ é a flexibilização da ordem social advinda da compreensão de que deve haver dinamismo e maleabilidade, eis que a insegurança tem a capacidade de provocar o aumento da produtividade e da eficácia, elementos opostos à solidariedade. Jorge Vergara Estévez ao discorrer sobre a crítica do sociólogo francês à mundialização das ideias neoliberais recorda que ela se aplica à política econômica adotada pelo Fundo Monetário Internacional e pela Organização Mundial do Comércio "que se presenta como expresión de la

\footnotetext{
10 BOURDIEU, Pierre. Contrafogos 2: por um movimento social europeu, p. 30.

11 BOURDIEU, Pierre. Contrafogos 2: por um movimento social europeu, p. 31.

12 BOURDIEU, Pierre. Contrafogos 2: por um movimento social europeu, p. 31, 33.

13 BOURDIEU, Pierre. Contrafogos 2: por um movimento social europeu.
} 
CADEMARTORI, Daniela Mesquita Leutchuk de; CAMPOS, Luciana Oliveira. Democracia e participação social efetiva: confrontação agonística como instrumento de legitimação dos atos das Agências Reguladoras brasileiras. Revista Eletrônica Direito e Política, Programa de Pós-Graduação Stricto Sensu em Ciência Jurídica da UNIVALI, Itajaí, v.13, n.3, $3^{\circ}$ quadrimestre de 2018. Disponível em: www.univali.br/direitoepolitica - ISSN 1980-7791

teoría económica, y la cual se ha convertido en un programa político" que se identifica "con la racionalidad individual". ${ }^{14}$

Lamentavelmente o modelo político-econômico norte-americano inadequado à realidade fática de muitos países acabou por ser implementando em uma onda de universalização que acabou por favorecer o referido sistema, já que passou a contar com "vantagem competitiva, prática e, também, simbólica". ${ }^{15}$ Observe-se que a vantagem é resultante do poder simbólico compreendido como o "poder invisível, o qual só pode ser exercido com a cumplicidade daqueles que não querem saber que lhe estão sujeitos ou mesmo que o exercem". ${ }^{16} \mathrm{O}$ poder simbólico por sua vez se concretiza na medida em que o sistema político-econômico dos Estados Unidos é uma espécie de poder estruturado e estruturante, cujo efeito ocorre pela incorporação progressiva de práticas determinadas. ${ }^{17}$ Assim, por meio da unificação do modelo econômico que promove concentração de poder e exclusão social, todos são postos "em um mesmo jogo" sem que estejam em igualdade de condições. ${ }^{18}$

O processo de reforma no Brasil começou a ser levado a efeito durante os anos noventa, iniciando com a privatização de empresas públicas produtivas e não prestadoras de serviços públicos. Contudo, a partir de 1995 a reforma ganhou força no sentido de transformar o Estado em gestor, ampliando as privatizações e chegando a desestatização de serviços públicos essenciais como o de energia elétrica, o que exigiu uma série de alterações de ordem legislativa, incluindo Emendas à Constituição Federal, a edição de leis e regulamentos, ${ }^{19}$ voltadas a viabilizar a implementação do regime de concessão e permissão de serviços públicos, o que por sua vez impôs a constituição de um modelo de regulação que

\footnotetext{
${ }^{14}$ VERGARA ESTÉVEZ, Jorge. La utopía neoliberal y sus críticos, p. 50.

15 BOURDIEU, Pierre. Contrafogos 2: por um movimento social europeu, p. 29.

16 BOURDIEU, Pierre. O poder simbólico. Tradução de Fernando Tomaz. 9. ed. Rio de Janeiro: Bertrand Brasil, 2006, p. 07-08.

17 BOURDIEU, Pierre. O poder simbólico.

18 BOURDIEU, Pierre. Contrafogos 2: por um movimento social europeu, p. 99.

19 LEHFELD, Lucas de Souza. Controles das agências reguladoras. São Paulo: Atlas, 2008, p. 207.
} 
CADEMARTORI, Daniela Mesquita Leutchuk de; CAMPOS, Luciana Oliveira. Democracia e participação social efetiva: confrontação agonística como instrumento de legitimação dos atos das Agências Reguladoras brasileiras. Revista Eletrônica Direito e Política, Programa de Pós-Graduação Stricto Sensu em Ciência Jurídica da UNIVALI, Itajaí, v.13, n.3, $3^{\circ}$ quadrimestre de 2018. Disponível em: www.univali.br/direitoepolitica - ISSN 1980-7791

possibilitasse ao Estado manter para si a competência de planejamento, regulação e fiscalização do serviço público privatizado. ${ }^{20}$

Ao mesmo tempo em que o governo desejava manter a gestão dos serviços, era preciso atrair investidores privados interessados em assumir a prestação dos serviços e fazer os investimentos necessários. ${ }^{21}$ Conseguir investidores estrangeiros mostrava-se um desafio porque estes exigiam do Brasil a redução dos riscos sobre seus investimentos, especialmente os que poderiam advir de um processo eleitoral no qual a esquerda viesse a ser vencedora e acabasse por romper contratos e estatizar empresas.

A blindagem política postulada por possíveis investidores conduziu à adoção do modelo de regulação norte-americano dos anos trinta de regulação por agências independentes, cujo formato asseguraria esta "blindagem institucional". ${ }^{22}$ Ao adotar o modelo regulatório dos Estados Unidos da América dos anos trinta, o Brasil desconsiderou todas as mudanças que referido modelo havia sofrido em seu país de origem desde a década de sessenta do século passado. Mudanças importantes como a independência das agências e a inclusão da participação social nos processos normativos conduzidos por referidas entidades foram desconsideradas no momento em que foi adotado_um modelo desatualizado. ${ }^{23}$

\section{LEGITIMAÇÃO DOS ATOS DAS AGÊNCIAS REGULADORAS: A NECESSÁRIA PARTICIPAÇÃO SOCIAL AGONÍSTICA COMO INSTRUMENTO DE SUPERAÇÃO DO DÉFICIT DEMOCRÁTICO}

Como já mencionado a Agência Nacional de Energia Elétrica-ANEEL foi a primeira agência reguladora brasileira, instituída pela Lei no 9427/1996 e constituída pelo Decreto 2335/1997, tendo como objetivo a regulação e fiscalização do serviço

20 ARAGÃO, Alexandre Santos de. Agências reguladoras e a evolução do direito administrativo econômico. 3. ed. Rio de Janeiro: Forense, 2013, p. 274.

${ }^{21}$ CAÉLLAR, Leila. As agências reguladoras e seu poder normativo. São Paulo: Dialética, 2001.

22 BINENBOJM, Gustavo. Uma teoria do direito administrativo: direitos fundamentais, democracia e constitucionalidade. Rio de Janeiro: Renovar, 2014, p. 287.

${ }^{23}$ DI PIETRO, Maria Sylvia Zanella. Parcerias na administração pública: concessão, permissão, franquia, terceirização e outras formas. 3. ed. São Paulo: Atlas, 1999. 
CADEMARTORI, Daniela Mesquita Leutchuk de; CAMPOS, Luciana Oliveira. Democracia e participação social efetiva: confrontação agonística como instrumento de legitimação dos atos das Agências Reguladoras brasileiras. Revista Eletrônica Direito e Política, Programa de Pós-Graduação Stricto Sensu em Ciência Jurídica da UNIVALI, Itajaí, v.13, n.3, $3^{\circ}$ quadrimestre de 2018. Disponível em: www.univali.br/direitoepolitica - ISSN 1980-7791

público de energia elétrica compreendendo atividades de geração, transmissão, comercialização e distribuição da energia. Após, foram criadas outras agências em âmbito federal, tais como: Agência Nacional das Águas - ANA, Agência Nacional de Saúde Suplementar - ANS, Agência Nacional do Petróleo - ANP, Agência Nacional da Aviação Civil - ANAC, Agência Nacional de telecomunicações -ANATEL, Agência Nacional de Vigilância Sanitária - ANVISA, Agência Nacional de Transportes Terrestres - ANTT. Existem ainda agências estaduais a exemplo da AGERGS - Agência Estadual de Regulação dos Serviços Públicos Delegados do Rio Grande do Sul e municipais como a ARSER - Agência Municipal de Regulação de Serviços Delegados de Maceió.

As Agências Reguladoras de âmbito federal, em que pese as peculiaridades do setor regulado, são dotadas de características básicas comuns oriundas do modelo norte-americano, com destaque para aquelas que Ihes conferem autonomia reforçada em suas áreas de atuação. Referida autonomia reforçada está relacionada ao grau de independência que dispõem para o exercício de suas atividades, blindadas da interferência tanto do poder público, quanto dos usuários e agentes regulados

A independência política e a autonomia reforçada são asseguradas por características como:

a) Estabilidade provisória de seus diretores. A gestão por diretoria colegiada cujos membros, nomeados pelo presidente da República, após aprovação do Senado, exercem mandatos intercalados, os quais não podem ser destituídos de seus cargos ad nutum, conferindo-Ihes estabilidade temporária para o exercício do seu mandato;

b) Ausência de interferência do poder público. Apesar de serem vinculadas aos Ministérios titulares dos setores regulados inexiste subordinação hierárquica institucional, assegurando

c) Independência financeira assegurada por recursos próprios;

d) Gestão e operação por especialista. São entidades cujos diretores e técnicos são especialistas detentores de conhecimentos singulares afetos ao setor regulado em que atuam. A especialização em área de atuação inacessível por leigos 
CADEMARTORI, Daniela Mesquita Leutchuk de; CAMPOS, Luciana Oliveira. Democracia e participação social efetiva: confrontação agonística como instrumento de legitimação dos atos das Agências Reguladoras brasileiras. Revista Eletrônica Direito e Política, Programa de Pós-Graduação Stricto Sensu em Ciência Jurídica da UNIVALI, Itajaí, v.13, n.3, $3^{\circ}$ quadrimestre de 2018. Disponível em: www.univali.br/direitoepolitica - ISSN 1980-7791

assegura uma espécie de superioridade técnica e consequentemente um poder simbólico. A justificativa apresentada para dotar as agências de corpo técnico altamente especializado é o grau de complexidade e dinamismo que envolvem os setores regulados, o que provoca a necessidade de uma regulação qualificada e dinâmica, tarefa à qual o legislativo não é capaz de atender com a especificidade e no tempo exigido.

As Agências Reguladoras brasileiras exercem tanto a regulação quanto a fiscalização dos setores em que atuam. No que tange a atividade de regulação propriamente dita, seu campo de atuação é estabelecido por leis, que fixam standards, diretrizes e políticas públicas, representando um importante espaço regulatório a ser exercido com uma "discricionariedade consideravelmente ampla"24 e, em regra, pouco questionada, uma vez que contam com autonomia reforçada, bem como com o poder simbólico da atuação dos especialistas que fazem sobrepor suas opiniões. ${ }^{25}$

A especialização das agências acaba por imprimir um grau de superioridade técnica, o que conduz a uma dificuldade fática de virem a sofrer contestações ou até mesmo fiscalização, eis que aqueles que não são especialistas acabam por não ter condições efetivas de realizar estas tarefas. Esse tipo de problema é apontado nas críticas à mundialização das ideias neoliberais perpetradas por Pierre Bourdieu, o qual, pontualmente sobre a especialização, sustenta a necessidade de acabar com o que denomina de "tirania dos 'especialistas" 26 , alertando que a atuação dos especialistas tem o poder de elevar a tecnocracia a uma condição de superioridade e consequente domínio de assuntos que deveriam ser objeto de discussão e decisão democrática. ${ }^{27}$

24 ARAGÃO, Alexandre Santos de. Agências reguladoras e a evolução do direito administrativo econômico, p. 442.

25 BARROSO, Luís Roberto. Agências reguladoras. Constituição, Transformações do Estado e legitimidade democrática. Revista de Direito da Procuradoria Geral, Rio de Janeiro, n. 56, 2002, p. 2012. Disponível em: <http://www.rj.gov.br/web/pge/exibeConteudo?article-id=780277>. Acesso em 20 set. 2018.

${ }^{26}$ BOURDIEU, Pierre. Contrafogos 1: táticas para enfrentar a invasão neoliberal. Tradução de Lucy Magalhães. Rio de Janeiro: Jorge Zahar, 1998, p. 38-39.

27 Aqui é importante mencionar, como um contraponto o tema das promessas não cumpridas pela democracia, conforme abordadas por Norberto Bobbio. Segundo ele uma das promessas que não 
CADEMARTORI, Daniela Mesquita Leutchuk de; CAMPOS, Luciana Oliveira. Democracia e participação social efetiva: confrontação agonística como instrumento de legitimação dos atos das Agências Reguladoras brasileiras. Revista Eletrônica Direito e Política, Programa de Pós-Graduação Stricto Sensu em Ciência Jurídica da UNIVALI, Itajaí, v.13, n.3, $3^{\circ}$ quadrimestre de 2018. Disponível em: www.univali.br/direitoepolitica - ISSN 1980-7791

\section{Ao explicar as transformações Boaventura de Sousa Santos ${ }^{28}$ explicando as} mudanças no final do século XX referentes ao debate democrático, lembra que a ampliação do modelo hegemônico liberal incluiu países nos quais as condições do campesinato e dos processos de urbanização eram muito diferentes, sendo que a desestruturação do modelo do Estado-Providência não produziu os efeitos distributivos de um modelo democrático.

Neste contexto ressurge a discussão acerca dos problemas da democracia dos países do Sul incluindo a questão estruturante, bem como os referentes as formas e variações dos modelos democráticos. A problemática que gira entorno da qualidade da democracia e a deterioração das práticas democráticas demonstra que a concepção hegemônica da democracia ${ }^{29}$ falhou, especialmente porque as teorias democráticas liberais -de natureza elitista-, não estimulam a expansão dos processos democráticos e a participação social. Assim, provocam uma crise no exercício democrático fruto de uma "dupla patologia": a que recai sobre a participação em si, responsável pelo crescimento das abstenções e a que diz respeito a representação, uma vez que os eleitos não representam os interesses dos eleitores.

poderia ser cumprida está a do governo dos técnicos, eis que "[...] o projeto político democrático foi idealizado para uma sociedade muito menos complexa que a de hoje." A transformação da sociedade civil impõe três obstáculos imprevistos, sendo relação antitética entre tecnocracia e democracia o primeiro deles, pois: "[...] se o protagonista da sociedade industrial é o especialista, impossível que venha a ser o cidadão qualquer. A democracia sustenta-se sobre a hipótese de que todos podem decidir a respeito de tudo. A tecnocracia, ao contrário, pretende que sejam convocados para decidir apenas aqueles que detém conhecimentos específicos. Na época dos estados absolutos [...] o vulgo devia ser mantido longe dos arcana imperii porque considerado ignorante demais. Hoje o vulgo é certamente menos ignorante. Mas os problemas a resolver tais como a luta contra a inflação, o pleno emprego, uma mais justa distribuição de renda - não se tornaram por acaso crescentemente mais complicados? Não são eles de tal envergadura que requerem conhecimentos científicos e técnicos em hipótese alguma menos misteriosos para o homem médio de hoje (que apesar de tudo é mais instruído)?" (BOBBIO, Norberto. O Futuro da Democracia. Uma defesa das regras do jogo. Tradução de M. A. Nogueira. Rio de Janeiro: Paz e Terra, 1986, p. 33-34).

28 SANTOS, Boaventura de Sousa. A Difícil democracia. Reinventar as esquerdas. São Paulo: Boitempo, 2016, p.17.

29 São elementos da concepção hegemônica das democracias: " [...] a tão apontada contradição entre mobilização e institucionalização; a valorização positiva da apatia política, ideia muito salientada por Schumpeter, para quem o cidadão comum não tinha capacidade nem interesse político senão para escolher os líderes a quem incumbiria tomar as decisões; a concentração do debate democrático na questão dos desenhos eleitorais das democracias; o tratamento do pluralismo como forma de incorporação partidária e disputa entre as elites e a solução minimalista para o problema da participação via discussão das escalas e da complexidade." (SANTOS, Boaventura de Sousa. A Difícil democracia. Reinventar as esquerdas, p. 17). 
CADEMARTORI, Daniela Mesquita Leutchuk de; CAMPOS, Luciana Oliveira. Democracia e participação social efetiva: confrontação agonística como instrumento de legitimação dos atos das Agências Reguladoras brasileiras. Revista Eletrônica Direito e Política, Programa de Pós-Graduação Stricto Sensu em Ciência Jurídica da UNIVALI, Itajaí, v.13, n.3, 30 quadrimestre de 2018. Disponível em: www.univali.br/direitoepolitica - ISSN 1980-7791

É justamente na associação da autonomia "em relação ao poder constituído" e do amplo e importante espaço regulatório concedido pelo Poder Legislativo às agências que se dá o déficit democrático e consequentemente um problema de legitimidade que recai sobre os atos das agências reguladoras. ${ }^{30}$

Na história da democracia no Brasil até o advento da promulgação da Constituição Federal de 1988 a legitimidade era assegurada a partir do voto, ou seja, o exercício da democracia se dava em sua forma representativa. As leis e o processo legislativo em si asseguravam a legitimidade. Contudo, o tema passou a ter outros contornos a partir da promulgação da Constituição de 1988, cuja disposição de seu art. 10, parágrafo único garante a todos os brasileiros e brasileiras o exercício da democracia em igualdades de condições, seja por meio do voto direto e secreto (na sua forma procedimental) seja por meio da participação direta.

Essa mudança representou a perda do "monopólio do Direito" por parte do Estado, o qual passa a ter o dever de garantir e promover participação social na administração pública, passando a condição subsidiária em relação à sociedade. A Carta Política instituiu o direito dos cidadãos de participar efetivamente das decisões administrativas, notadamente quando estas tiverem o potencial de afetar seus interesses, como no caso da prestação de serviços públicos regulados.

A sonegação desse direito aos cidadãos pode ensejar a "nulidade do ato", bem como a "responsabilização de seu emissor", pois o direito da sociedade de participar democraticamente das decisões administrativas faz recair sobre o gestor público o dever de promoção da participação social. ${ }^{31}$

A previsão expressa no texto constitucional acerca do princípio democrático sem dúvida foi um avanço importante, ao passo que lhe confere força cogente sobre o ordenamento jurídico como um todo, devendo ser observada por todo o gestor público. Mas a disposição constante na Carta Política não é suficiente para garantir

\footnotetext{
${ }^{30}$ AGUILLAR, Fernando Herren. Controle social de serviços públicos, p. 233.

${ }^{31}$ MOREIRA, Egon Bockmann; SOARES JÚNIOR, Lauro Antônio Nogueira. Regulação econômica e democracia: a questão das agências administrativas independentes. In: BINENBOJM, Gustavo (or.). Agências reguladoras e democracia. Rio de Janeiro: Lumen Juris, 2006, p. 194.
} 
CADEMARTORI, Daniela Mesquita Leutchuk de; CAMPOS, Luciana Oliveira. Democracia e participação social efetiva: confrontação agonística como instrumento de legitimação dos atos das Agências Reguladoras brasileiras. Revista Eletrônica Direito e Política, Programa de Pós-Graduação Stricto Sensu em Ciência Jurídica da UNIVALI, Itajaí, v.13, n.3, $3^{\circ}$ quadrimestre de 2018. Disponível em: www.univali.br/direitoepolitica - ISSN 1980-7791

sua efetividade, entendida esta como algo que vai além da simples possibilidade de participação.

A participação social efetiva capaz de agregar legitimidade aos atos decisórios exige mais que a simples disponibilização de canais de transparência e de participação, requer a adoção de medidas eficientes na mobilização social à participação e, além disso, mecanismos diferentes que viabilizem a pluralidade de vozes existentes na sociedade complexa se fazerem ouvir. Promover a participação social nestes moldes em uma sociedade fragmentada socialmente pelo "confronto entre 'incluídos' e 'excluídos" é um grande desafio. A falta de "um sentido mínimo de participação e solidariedade", inviabiliza a constituição de uma consciência social coletiva e politicamente ativa. Na contramão, o que se vivencia na atualidade é o "crescente desprestígio da própria democracia conquistada nos anos 80 e de um subsequente esvaziamento de seu significado como valor fundamental", uma apatia política onde impera a necessidade de ativa participação social. ${ }^{32}$

Em que pese o modelo de democracia liberal permanecer vigente, a questão da legitimidade das decisões exige procedimentos inclusivos de participação igualitária dos cidadãos. ${ }^{33}$ Nas palavras de Dierle José Coelho Nunes, a legitimidade na tomada de decisões e solução de conflitos perpassa necessariamente por procedimentos de promoção de participação social de forma efetiva e igualitária inserindo assim, os indivíduos na elaboração da norma, de tal modo que a legitimação do direito "se dá pela empreitada cooperativa, que se apresenta por meio de procedimentos que possibilitam a participação igualitária e efetiva de todos os interessados no processo de produção das leis, bem como no processo de aplicação das normas". ${ }^{34}$

\footnotetext{
32 FARIA, José Eduardo (Org.). Direito e globalização econômica: implicações e perspectivas. São Paulo: Malheiros, 1998, p. 146-147

33 A respeito da perspectiva da teoria discursiva habermasiana de democracia, ver por todos: CADEMARTORI, D. M. L. de; STAFFEN, M. R. A Função democrática do princípio do contraditório no processo administrativo disciplinar. Revista Direitos Fundamentais \& Justiça. PUC/RS, Porto Alegre, v. 12, s. 12, p. 235-246, 2010.

34 NUNES, Dierle José Coelho. Direito constitucional ao recurso: da teoria geral dos recursos, das reformas processuais e da comparticipação das decisões. Rio de Janeiro: Lúmen Juris, 2006, p. 52.
} 
CADEMARTORI, Daniela Mesquita Leutchuk de; CAMPOS, Luciana Oliveira. Democracia e participação social efetiva: confrontação agonística como instrumento de legitimação dos atos das Agências Reguladoras brasileiras. Revista Eletrônica Direito e Política, Programa de Pós-Graduação Stricto Sensu em Ciência Jurídica da UNIVALI, Itajaí, v.13, n.3, $3^{\circ}$ quadrimestre de 2018. Disponível em: www.univali.br/direitoepolitica - ISSN 1980-7791

Na mesma linha Habermas assevera que de forma diversa do paradigma oriundo da democracia liberal, bem como do Estado Social, não se mostra mais viável a antever o ideal de determinada sociedade,

[...] nem uma determinada visão de boa ou uma determinada opção política. Pois ele é formal no sentido que apenas formula as condições necessárias segundo as quais os sujeitos do direito podem, enquanto cidadãos, entender-se entre si para descobrir seus problemas e o modo de solucioná-los. ${ }^{35}$

A razão instrumental típica da modernidade é substituída por uma razão comunicativa emancipatória que defende a democracia, como um modelo constitucional oriundo de manifestações opinativas populares. Recorde-se que acima de tudo, neste caso a linguagem passa a apelar para a cognição. Com base no corpo cognitivo da linguagem, diz Habermas, esse discurso em condição livre discurso que se coloca contra o discurso do outro, sem o intuito dominador, mas exatamente para ser compreendido -, encontra aí a substância nuclear da linguagem, base para todos os outros discursos, do saber, do esclarecimento e das decisões ${ }^{36}$.

Manuel Atienza, discorrendo sobre a passagem da ação para o discurso recorda que comumente as pretensões de validade dos atos de fala são aceitas com um certo grau de ingenuidade. ${ }^{37}$ No caso em que ocorra a problematização das pretensões de verdade ou de correção,

[...] ocorre a passagem da ação (ação comunicativa) para o que Habermas chama de discurso. Isso quer dizer que o falante tem de dar razões para fundamentar que suas asserções sejam verdadeiras (discurso teórico) ou que uma determinada ação ou norma de ação seja correta (discurso

35 HABERMAS, Jürgen. Direito e moral (Tanner Lectures, 1986). In: Direito e democracia: entre facticidade e validade. Tradução de Flavio Beno Siebeneichler. 2.ed. Rio de Janeiro: Tempo Brasileiro, 2003a, v. II, p. 193-248, Título original: Faktizität und Geltung, p. 190.

36 Rosa destaque a Teoria da Ação Comunicativa de Habermas justifica-se trazendo como pressuposto: I- que todos compartilham de regras semânticas igualmente inteligível; II- a verdade acerca daquilo que é dito; III- os direitos sociais e/ou normas são justificativas invocadas pelo emissor; IV- a sinceridade do. "Em suma, não pode ser uma comunicação distorcida." (ROSA, Alexandre Morais da. Decisão penal: bricolage de significantes. Rio de Janeiro: Lúmen Juris, 2006, p. 268).

37 ATIENZA, Manuel. As razões do direito. Teorias da argumentação jurídica. Tradução de Maria Cristina Guimarães Cupertino. 3.ed. São Paulo: Landy, 2003. 
CADEMARTORI, Daniela Mesquita Leutchuk de; CAMPOS, Luciana Oliveira. Democracia e participação social efetiva: confrontação agonística como instrumento de legitimação dos atos das Agências Reguladoras brasileiras. Revista Eletrônica Direito e Política, Programa de Pós-Graduação Stricto Sensu em Ciência Jurídica da UNIVALI, Itajaí, v.13, n.3, $3^{\circ}$ quadrimestre de 2018. Disponível em: www.univali.br/direitoepolitica - ISSN 1980-7791

prático). No que se refere às outras duas pretensões, a de inteligibilidade é condição, mas não objeto, da comunicação (e dá lugar ao que Habermas chama de 'discurso explicativo'), e a de veracidade não é resolvida discursivamente: se um falante é ou não sincero, só se pode reconhecer em suas ações. ${ }^{38}$

A formação da opinião, bem como da vontade destacada na teoria do discurso coloca a Constituição como elemento primordial: "concebe os princípios do Estado Constitucional como resposta consistente à questão de como podem ser institucionalizadas as exigentes formas comunicativas de uma formação democrática da vontade e da opinião. ${ }^{39}$

De forma sintetizada, segundo Habermas, é o modelo procedimentalista que legitima o Estado Democrático de Direito, com fundamento na política deliberativa. Assim, o princípio democrático tem a função de "enquadrar" procedimentos de normatização do direito legítimos. ${ }^{40} \mathrm{O}$ que equivale dizer que a legitimidade das leis depende da existência de aquiescência de todos os participantes do processo discursivo de normatização. Conforme o autor, no entrelaçamento entre o princípio do discurso e a forma jurídica está a origem lógica dos direitos, que pode ser reconstruída de modo paulatino.

Ela começa com a aplicação do princípio do discurso ao direito de liberdade subjetivas de ação em geral - constitutivo para a forma jurídica. Por isso, o princípio da democracia só pode aparecer como núcleo de um sistema de direitos. A gênese lógica desses direitos forma um processo circular no qual o código do direito e o mecanismo para a produção de direito legítimo, portanto o princípio da democracia, se constituem de modo co-originário. ${ }^{41}$

38 HABERMAS, Jürgen. Direito e democracia: entre facticidade e validade. 2.ed. Tradução de Flavio Beno Siebeneichler. Rio de Janeiro: Tempo Brasileiro, 2003, v. I, p. 182.

39 HABERMAS, Jürgen. Três modelos normativos de democracia. Tradução de Anderson Fortes Almeida e Acir Pimenta Madeira. Cadernos da Escola do Legislativo. Belo Horizonte, n. 3, p. 107-121, jan./jun. 1995, p. 117.

40 HABERMAS, Jürgen. Política deliberativa: um conceito procedimental de democracia. In: Direito e democracia: entre facticidade e validade. Tradução de Flavio Beno Siebeneichler. 2.ed. Rio de Janeiro: Tempo Brasileiro, 2003, v. II, p. 9-56, Título original: Faktizität und Geltung.

41 HABERMAS, Jürgen. Para uma reconstrução do direito (I): o sistema dos direitos. In:

Direito e democracia: entre facticidade e validade. Tradução de Flavio Beno Siebeneichler. 2.ed. Rio de Janeiro: Tempo Brasileiro, 2003, v. I. Título original: Faktizität und Geltung, p. 158. 
CADEMARTORI, Daniela Mesquita Leutchuk de; CAMPOS, Luciana Oliveira. Democracia e participação social efetiva: confrontação agonística como instrumento de legitimação dos atos das Agências Reguladoras brasileiras. Revista Eletrônica Direito e Política, Programa de Pós-Graduação Stricto Sensu em Ciência Jurídica da UNIVALI, Itajaí, v.13, n.3, $3^{\circ}$ quadrimestre de 2018. Disponível em: www.univali.br/direitoepolitica - ISSN 1980-7791

Sendo assim, a Constituição deve ser compreendida de modo a articular-se com uma visão linguística-discursiva da democracia, percebida, essencialmente, como a interpretação e a estruturação de um sistema de direitos fundamentais que subsidia as condições procedimentais de institucionalização jurídica das formas de comunicação ${ }^{42}$.

Neste sentido, Habermas reafirma a ideia de que "uma ordem política livremente estabelecida pela vontade do povo de modo que os destinatários das normas legais podem, ao mesmo tempo, se reconhecerem como autores das leis". Existe na linguagem uma função fundamental para os envolvidos nos processos de integração social, de inclusão e de cognição racional, pedra angular de todos os outros discursos, que exige uma nova postura dos interessados no provimento jurisdicional guiado sempre por um processo comunicativo-constitucionaldemocrático. ${ }^{43}$

A prática argumentativa exige que os participantes pressuponham, em princípio, que todos possivelmente afetados tenham condições de participar de forma livre e igual, seguindo um modelo de "garimpagem cooperativa" na construção da verdade, contexto no qual o argumento é a única forma coercitiva admissível. Desta forma o procedimento ao invés de ser uma luta na qual adversários procuram eliminar uns aos outros, se transforma em um jogo no qual prevalece a racionalidade dos participantes ${ }^{44}$.

\section{A necessária confrontaÇÃo Agonística nOS PROCESSOS DE AUDIÊNCIAS E CONSULTAS PÚBLICAS PROMOVIDOS PELAS AGÊNCIAS REGULADORAS}

Chantal Mouffe trabalha sua teoria de democracia radical plural tendo como ponto de partida a teoria deliberativa de Habermas, divergindo no que tange à ideia de consenso, sustentando neste ponto algo oposto, ou seja, o dissenso. Isso porque

\footnotetext{
42 OLIVEIRA, Marcelo Antonio Cattoni de. Direito processual constitucional. Belo Horizonte: Mandamentos, 2001, p. 257.

43 HABERMAS, Jürgen. O estado nação europeu frente os desafios da globalização. Revista Novos Estudos CEBRAP. São Paulo, n. 43, p. 65-110, nov. 1995, p. 92.

${ }^{44}$ HABERMAS, Jürgen. Direito e moral, p. 215.
} 
CADEMARTORI, Daniela Mesquita Leutchuk de; CAMPOS, Luciana Oliveira. Democracia e participação social efetiva: confrontação agonística como instrumento de legitimação dos atos das Agências Reguladoras brasileiras. Revista Eletrônica Direito e Política, Programa de Pós-Graduação Stricto Sensu em Ciência Jurídica da UNIVALI, Itajaí, v.13, n.3, $3^{\circ}$ quadrimestre de 2018. Disponível em: www.univali.br/direitoepolitica - ISSN 1980-7791

a autora vê as relações sociais como agonísticas e assim, repletas de diversidades e conflitos, cujo desafio imposto a democracia está na necessidade de constituição de poder condizente com os valores democráticos em que a existência de conflito é algo posto como essencial a existência da democracia. ${ }^{45}$

A teoria da democracia radical plural de Mouffe nasceu a partir de trabalho realizado em conjunto com Ernesto Laclau intitulado Hegemonia e Estratégia Socialista: por uma política democrática radical (1985), no qual se posicionaram de forma contrária à ideia de hegemonia única ao sustentarem que a sociedade é constituída por inúmeras identidades "constituídas a partir de relações discursivas antagônicas distintas do mero antagonismo de classe", daí a compreensão de complexidade social incompatível com a concepção de hegemonia. ${ }^{46}$

Para Laclau e Mouffe, o social é constituído pelo antagonismo e a hegemonia é contingente. Os autores construíram sua concepção de hegemonia a partir da teoria de Antônio Gramsci, o qual, na visão dos autores, "ampliou o terreno da recomposição política e da hegemonia, ao mesmo tempo em que ofereceu uma teorização do vínculo hegemônico que ia claramente além da categoria leninista de 'aliança de classes", ao revisitar a ideia leninista de liderança "meramente política" promovendo o deslocamento em direção a concepção de liderança 'intelectual e moral', na forma de uma "vontade coletiva", capaz de se tornar uma espécie de "cimento orgânico que unifica um 'bloco histórico"". 47

De acordo com Laclau e Mouffe o deslocamento proposto por Gramsci dá visibilidade ao vínculo hegemônico de forma teorizada, contexto em que a ideologia tem papel central. Rompe a "problemática reducionista da ideologia" de modo que os sujeitos políticos passam a ser vislumbrados não mais como classes, e sim, como "vontades coletivas' complexas" resultante da "articulação político-

45 MOUFFE, Chantal. Democracia, cidadania e a questão do pluralismo... e Sobre o Político. Tradução de Fernando Santos. São Paulo: Martins Fontes, 2015.

46 MENDONÇA, Daniel de. Teorizando o agonismo: crítica a um modelo incompleto. Revista Sociedade e Estado. Departamento de Sociologia da UnB, Brasília, v. 25, n.3, p. 479-497, set./dez. 2010, p. 481. Disponível em: <http://www.scielo.br/pdf/se/v25n3/04.pdf>. Acesso em: 21 set. 2018.

47 LACLAU, Ernesto; MOUFFE, Chantal. Hegemonia e Estratégia Socialista: por uma política democrática radical. Tradução de Joanildo A. Burity et al. São Paulo: Intermeios, 2015, p. 130,131. 
CADEMARTORI, Daniela Mesquita Leutchuk de; CAMPOS, Luciana Oliveira. Democracia e participação social efetiva: confrontação agonística como instrumento de legitimação dos atos das Agências Reguladoras brasileiras. Revista Eletrônica Direito e Política, Programa de Pós-Graduação Stricto Sensu em Ciência Jurídica da UNIVALI, Itajaí, v.13, n.3, $3^{\circ}$ quadrimestre de 2018. Disponível em: www.univali.br/direitoepolitica - ISSN 1980-7791

ideológica de forças históricas dispersas e fragmentadas" colocando a "complexidade social como a condição mesma da luta política". ${ }^{48}$ Porém, divergem da teoria gramsciana por entenderem inviável a existência de "uma sociedade totalmente suturada", por identificarem "antagonismos", "externos" que inviabilizam a constituição de uma sociedade plena. ${ }^{49}$ Como destaca Ana Rodrigues Cavalcanti Alves, ao vislumbrarem o antagonismo como "constitutivo do social" apresentando "aberto e incompleto" inexiste, na concepção de Laclau e Mouffe, a "possibilidade de uma reconciliação final". 50

O vínculo hegemônico, conforme Laclau e Mouffe, é "constitutivamente político", resultado da lógica específica entre o que identificam como "lógica da diferença e lógica da equivalência". Os "discursos que constituem o tecido social" são oriundos de atores sociais diversos, os quais ocupam posições diferentes na construção dos referidos discursos. Embora referidos sujeitos sejam "particularidades", quando expostos a "forças opressoras" são capazes de estabelecerem "relações de equivalência entre si", o que não representa uma universalidade estável e sim, uma "relação hegemônica", posta como uma 'universalidade política" que pode sempre ser revertida. ${ }^{51}$

A articulação é elemento central no trabalho dos autores. A articulação hegemonica tem caráter político quando posta em prática no meio social, possibilitando que diferentes identidades e atores sociais de posições diversas "na relação com o outro" acabem por formar uma hegemonia. Segundo a teoria de Laclau e Mouffe, em um determinado momento e espaço, por meio da articulação dentre inúmeras individualidades e múltiplas alternativas, algumas sejam acolhidas e outras

\footnotetext{
48 LACLAU, Ernesto; MOUFFE, Chantal. Hegemonia e Estratégia Socialista: por uma política democrática radical, p. p. 130, 132, 134-136,137, 203.

49 OLIVEIRA, Francisco Mesquita de. Ações Coletivas, Cultura Política e Movimentos Sociais: disputas de significado e antagonismo no âmbito da reforma urbana. Tese (Doutorado Sociologia). Programa de Pós-Graduação em Sociologia. Universidade Federal de Pernambuco. Recife, 2010, p. 25. Disponível em: <http://repositorio.ufpe.br/handle/123456789/9274>. Acesso em: 21 set. 2018.

50 ALVES, Ana Rodrigues Cavalcanti. O conceito de hegemonia: de Gramsci a Laclau e Mouffe. Lua Nova. São Paulo, n. 80, p. 71-96, 2010. Disponível em: <http://www.scielo.br/pdf/ln/n80/04.pdf>. Acesso em 21 set. 2018, p. 71, 94.
}

51 LACLAU, Ernesto; MOUFFE, Chantal. Hegemonia e Estratégia Socialista: por uma política democrática radical, p. 40,41. Destaque dos autores 
CADEMARTORI, Daniela Mesquita Leutchuk de; CAMPOS, Luciana Oliveira. Democracia e participação social efetiva: confrontação agonística como instrumento de legitimação dos atos das Agências Reguladoras brasileiras. Revista Eletrônica Direito e Política, Programa de Pós-Graduação Stricto Sensu em Ciência Jurídica da UNIVALI, Itajaí, v.13, n.3, $3^{\circ}$ quadrimestre de 2018. Disponível em: www.univali.br/direitoepolitica - ISSN 1980-7791

rechaçadas. Aquelas que forem escolhidas formam o que denominam de hegemonia contingencial. ${ }^{52}$

A hegemonia formada por meio da articulação deve ser compreendida como uma "totalidade relacional"53, expressão de "uma 'vontade coletiva"54 fruto da hegemonização de uma 'pluralidade de atores'55 e não com a construção de uma identidade plena.

É o antagonismo entre diferentes atores que possibilita a articulação e a formação de hegemonia contingencial. Por meio da "equivalência", 56 elementos que não são totalmente comuns, ante o outro que é antagônico -o "outro que difere" - são unificados de forma "equivalencial"57 construindo uma identidade social formada por certos "elementos ou valores"58 excluindo os que são opositores - o outro antagônico.

Após o trabalho realizado em conjunto com Laclau, a cientista política passou a escrever sobre a ideia de uma democracia plural radical arguindo uma diferença entre político e política, na qual o político é colocado como de ordem ontológica com destaque para o antagonismo formador das sociedades. A política é definida como o "conjunto de práticas e instituições por meio das quais uma ordem é criada,

\footnotetext{
52 LOPES, Alice Casimiro; MENDONÇA, Daniel de; BURITY, Joanildo A. A Contribuição de Hegemonia e estratégia socialista para as ciências humanas e sociais. In LACLAU, Ernesto; MOUFFE, Chantal. Hegemonia e Estratégia Socialista: por uma política democrática radical. Tradução de Joanildo A. Burity et al. São Paulo: Intermeios, 2015, p. 16.
}

53 OLIVEIRA, Francisco Mesquita de. Ações Coletivas, Cultura Política e Movimentos Sociais: disputas de significado e antagonismo no âmbito da reforma urbana, p. 24.

54 OLIVEIRA, Francisco Mesquita de. Ações Coletivas, Cultura Política e Movimentos Sociais: disputas de significado e antagonismo no âmbito da reforma urbana, p. 25.

55 LACLAU, Ernesto; MOUFFE, Chantal. Hegemonia e Estratégia Socialista: por uma política democrática radical, p. 178.

56 OLIVEIRA, Francisco Mesquita de. Ações Coletivas, Cultura Política e Movimentos Sociais: disputas de significado e antagonismo no âmbito da reforma urbana, p. 28.

57 LACLAU, Ernesto; MOUFFE, Chantal. Hegemonia e Estratégia Socialista: por uma política democrática radical, p. 250.

58 LACLAU, Ernesto; MOUFFE, Chantal. Hegemonia e Estratégia Socialista: por uma política democrática radical, p. 250. 
CADEMARTORI, Daniela Mesquita Leutchuk de; CAMPOS, Luciana Oliveira. Democracia e participação social efetiva: confrontação agonística como instrumento de legitimação dos atos das Agências Reguladoras brasileiras. Revista Eletrônica Direito e Política, Programa de Pós-Graduação Stricto Sensu em Ciência Jurídica da UNIVALI, Itajaí, v.13, n.3, $3^{\circ}$ quadrimestre de 2018. Disponível em: www.univali.br/direitoepolitica - ISSN 1980-7791

organizando a coexistência humana no contexto conflituoso produzido pelo político. ${ }^{59}$

Visualizando o poder como constituidor de identidades em um espaço "precário e sempre vulnerável", Chantal Mouffe propôs uma nova forma de ver a relação "entre democracia e poder". A autora coloca que o modelo de "democracia radical plural" idealizada em conjunto com Laclau, não defende a eliminação do poder, ao contrário, exige a aceitação de que existem "relações de poder e a necessidade de transformá-las". Para tanto defende a construção de "formas de poder compatíveis com valores democráticos. ${ }^{60}$

A democracia na concepção de Mouffe considera que a legitimidade do poder deve ser fruto da contínua confrontação de sujeitos em uma sociedade ativa politicamente, capaz de construir, por meio do exercício da articulação e do antagonismo, a "conexão entre poder e legitimidade e a ordem hegemônica que ela acarreta".61

Para que o modelo de democracia plural radical seja compatível com o Estado democrático de direito é preciso transformar o "antagonismo em agonismo,"62 transformando a figura do inimigo em um simples adversário, criando-se um ambiente de reconhecimento recíproco da "legitimidade do oponente"63. A forma de realização desta transformação sustentada pela autora tem como ponto de partida a teoria de Carl Schmitt, que trabalha a figura do antagonismo baseada na distinção entre "nós-eles" como "amigo-inimigo", algo incompatível com o pluralismo democrático. Chantal Mouffe por sua vez, defende a compatibilidade do modelo com a democracia plural condicionada apenas à transformação do

59 LACLAU, Ernesto; MOUFFE, Chantal. Hegemonia e Estratégia Socialista: por uma política democrática radical, p. 08.

60 MOUFFE, Chantal. Democracia, cidadania e a questão do pluralismo. Tradução de K. Prudencio. Política \& Sociedade. UFSC, Florianópolis, v. 2, no 3, p. 11-26, 2003, p. 14. Disponível em: <https://periodicos.ufsc.br/index.php/politica/article/view/2015>. Acesso em: 22 set. 2018.

61 MOUFFE, Chantal. Por um modelo agonístico de democracia. Tradução de P. S. Ghetti. Revista de Sociologia Política. UFPR, Curitiba, n. 5, p. 11-23, nov. 2005. p. 20. Disponível em: http://www.scielo.br/pdf/rsocp/n25/31108.pdf. Acesso em: 22 set. 2018.

62 MOUFFE, Chantal. Sobre o Político. Tradução de Fernando Santos. São Paulo: Martins Fontes, 2015, p. 19.

63 MOUFFE, Chantal. Sobre o Político, p. 241. 
CADEMARTORI, Daniela Mesquita Leutchuk de; CAMPOS, Luciana Oliveira. Democracia e participação social efetiva: confrontação agonística como instrumento de legitimação dos atos das Agências Reguladoras brasileiras. Revista Eletrônica Direito e Política, Programa de Pós-Graduação Stricto Sensu em Ciência Jurídica da UNIVALI, Itajaí, v.13, n.3, 30 quadrimestre de 2018. Disponível em: www.univali.br/direitoepolitica - ISSN 1980-7791

"antagonismo em agonismo"64.Para tanto o inimigo vislumbrado por Carl Schmitt deve ser compreendido como adversário, - "categoria crucial para a política democrática"65_, estabelecendo, a partir de uma lógica oposta à "da equivalência e da diferença"66, uma relação entre amigo-adversário, viabilizada pela articulação empregada como instrumento de constituição de relações hegemônicas contingentes.

É o dissenso posto como elemento essencial que sustenta a tese de compatibilidade da democracia radical plural com o Estado democrático de direito ao ser apresentado como instrumento capaz de viabilizar a participação de diferentes identidades na arena da articulação e construção de hegemonia, tendo como ponto de partida a figura do outro como oponente legítimo. ${ }^{67} \mathrm{O}$ dissenso/conflito é colocado como essencial para a mobilização das "paixões"68 e consequente promoção da confrontação agonística. Nesse cenário o consenso se faz necessário apenas na definição de "princípios éticos-constitutivos", que devem garantir o exercício da confrontação de forma agonística e não antagonística, ou seja, uma confrontação em que o adversário seja reconhecido como opositor legítimo e não um inimigo. É preciso ainda, um ambiente adequado, preparado por instituições capazes de promover o conflito de forma agonística, e a construção, por meio da articulação de uma hegemonia que será sempre contingente. ${ }^{69}$

Ao transpor a teoria de democracia radical plural para o ambiente das Agências Reguladoras brasileiras, é possível vislumbrar o potencial e até o dever de que elas atuem como instituições promotoras do conflito de forma agonística, assegurando assim a participação de todos os agentes regulados e as diversas identidades que compõem a nossa sociedade complexa de forma efetiva. Desse modo os atos das

\footnotetext{
64 MOUFFE, Chantal. Sobre o Político, p. 19.

65 MOUfFE, Chantal. Sobre o Político, p. 19.

66 LACLAU, Ernesto; MOUFFE, Chantal. Hegemonia e Estratégia Socialista: por uma política democrática radical, p. 223.

67 KOZICKI, Katya. Prefácio In: MOUFFE, Chantal. Sobre o Político, 2015.

68 MOUFFE, Chantal. Democracia, cidadania e a questão do pluralismo, p. 17.

69 MOUFFE, Chantal. Por um modelo agonístico de democracia, p. 19.
} 
CADEMARTORI, Daniela Mesquita Leutchuk de; CAMPOS, Luciana Oliveira. Democracia e participação social efetiva: confrontação agonística como instrumento de legitimação dos atos das Agências Reguladoras brasileiras. Revista Eletrônica Direito e Política, Programa de Pós-Graduação Stricto Sensu em Ciência Jurídica da UNIVALI, Itajaí, v.13, n.3, $3^{\circ}$ quadrimestre de 2018. Disponível em: www.univali.br/direitoepolitica - ISSN 1980-7791

Agências poderão aumentar o seu grau de legitimidade, eis que superar-se-ia eventuais déficits democráticos, oriundos de sua forma constitutiva, notadamente os regulamentares sob os quais este déficit é maior.

As normas que constituíram as Agências Reguladoras brasileiras federais, em regra, preveem instrumentos de participação social de forma genérica e sem regulamentação, como, no caso da Agência Nacional de Energia Elétrica - ANEEL, responsável pela regulação e fiscalização dos serviços públicos de energia elétrica no Brasil. Tanto a Lei no 9.427/1996 em seu artigo 40, § 30, quanto o Decreto $n$ 2.335/1995 na forma do seu art. 21 estabelecem que, sempre que for possível, os processos cujas decisões afetarem direitos dos consumidores e dos agentes econômicos setoriais serão precedidos de audiências públicas, a serem realizadas com o objetivo de obter subsídios e informações, de modo a tornar pública a atividade da reguladora.

Observa-se na prática que a referida Agência promove inúmeras audiências e consultas públicas ao longo de cada ano. Contudo, a participação cidadã não é expressiva, nem mesmo representativa na tomada de decisão por parte da reguladora. O potencial de promoção da participação social das audiências públicas promovidas pela Agência Nacional de Energia Elétrica - ANEEL foi objeto de pesquisa empírica realizada a partir de estudo de caso realizado sobre a Audiência Pública 006/2015, ${ }^{70}$ a qual versou, em síntese, sobre a revisão do sistema das bandeiras tarifárias (tema de repercussão financeira sobre todo o território nacional). Por meio da técnica de "análise de conteúdo"71, a partir de conceitos de campo, habitus e capital de Pierre Bourdieu, além de alguns princípios que norteiam o agir do administrador público, foi realizada a análise de todos os documentos que compunham o processo desde abertura até encerramento. As conclusões apontaram entre outras coisas o domínio da técnica e a supremacia dos especialistas cujas posições são as que acabam prevalecendo, sendo que ficou

\footnotetext{
70 BRASIL. Agência Nacional de Energia Elétrica - ANEEL. Audiência Pública no 06/2015. Brasília, 2015. Disponível em: <http://www.aneel.gov.br/aplicacoes/audiencia/dspListaAudiencia.cfm?

attAnoAud=2015\&attAnoFasAud=2015\&id_area=13>. Acesso em: 21 set. 2018

71 BARDIN, Lawrence. Análise de conteúdo. Tradução de Luís Antero Reto e Augusto Pinheiro. São Paulo: Ed. 70, 2011.
} 
CADEMARTORI, Daniela Mesquita Leutchuk de; CAMPOS, Luciana Oliveira. Democracia e participação social efetiva: confrontação agonística como instrumento de legitimação dos atos das Agências Reguladoras brasileiras. Revista Eletrônica Direito e Política, Programa de Pós-Graduação Stricto Sensu em Ciência Jurídica da UNIVALI, Itajaí, v.13, n.3, $3^{\circ}$ quadrimestre de 2018. Disponível em: www.univali.br/direitoepolitica - ISSN 1980-7791

claro durante a análise que os cidadãos não são munidos do capital predominante naquele campo de luta, ou seja, o conhecimento técnico especializado. Questões como uso de linguagem técnica e a complexidade do material disponibilizado pela Agência, a falta de um procedimento devidamente regulamentado, a falta de clareza das informações, bem como de motivação das decisões foram problemas identificados durante a análise realizada. ${ }^{72}$

Processos como de audiências ou consultas públicas que não são efetivos na promoção da participação cidadã não podem ser considerados como instrumentos de legitimação, porque a simples publicação em sites oficiais de processos participativos cumprem apenas um papel formal. A cidadania, prevista no art. 10, inciso II da Constituição Federal como um dos fundamentos da República Federativa do Brasil, ante a complexidade e pluralidade da sociedade deve ser vista "como um direito mais abrangente", tendo presente que "exercer a cidadania é não estar submetido a amarras, quando da participação no processo político, bem como não encontrar óbices quando, perante a autoridade pública, exigir a efetiva distribuição da justiça social". ${ }^{73}$

A participação como elemento de legitimação é condição de constitucionalidade que deve ser observada por toda a administração pública, em todas as suas esferas. Essa condição ganha maior amplitude em relação às atividades das Agências Reguladoras porque além da questão constitucional, há que se considerar o problema do déficit democrático fruto da blindagem política que envolve tais instituições. Como destaca Cláudio Mastrangelo:

No âmbito da Administração Pública, o prestigiamento da participação popular coincide com o alvorecer de um novo tempo, ainda não percebido por muitos, mas que introduz concepção moderna, no sentido de ensejar à cidadania uma posição ativa nas tomadas de decisão e no próprio controle sobre suas ações. A essa altura, o destinatário deixa de ser

72 CAMPOS, Luciana Oliveira de. Setor Elétrico: Regulação e as audiências públicas promovidas pela ANEEL. Rio de Janeiro: Lumen Juris, 2018.

73 LEHFELD, Lucas de Souza. Controles das agências reguladoras, p. 28. 
CADEMARTORI, Daniela Mesquita Leutchuk de; CAMPOS, Luciana Oliveira. Democracia e participação social efetiva: confrontação agonística como instrumento de legitimação dos atos das Agências Reguladoras brasileiras. Revista Eletrônica Direito e Política, Programa de Pós-Graduação Stricto Sensu em Ciência Jurídica da UNIVALI, Itajaí, v.13, n.3, 30 quadrimestre de 2018. Disponível em: www.univali.br/direitoepolitica - ISSN 1980-7791

espectador e mero alvo para se constituir em protagonista, assumindo posição interativa com a Administração Pública. ${ }^{74}$

A concepção de democracia plural radical de Chantal Mouffe que comporta a ideia de que o exercício da "cidadania é um combate agonístico em ambiente plural radical, vivo, não universalmente determinado", mostra-se como um caminho importante a ser considerado nos processos de participação social a serem promovidos pelas Agências Reguladoras. Desse modo, a participação atuaria como um instrumento efetivo de legitimação, na qual as confrontações agonísticas das diferentes posições e identidades mediante exercício da articulação, da lógica da equivalência e da diferença, reconhecendo o outro como oponente, possa construir hegemonias contingentes. ${ }^{75}$

\section{CONSIDERAÇÕES FINAIS}

Há mais de vinte anos a regulação e a fiscalização de atividades essenciais ao desenvolvimento social, bem como econômico do país são atribuídas a autarquias dotadas de autonomia perante o poder constituído, denominadas Agências Reguladoras e concebidas conforme um modelo norte-americano da década de trinta do século passado, seguindo a onda de mundialização das ideias neoliberais.

O grau de autonomia concedido a estas entidades para o exercício de suas funções, que funcionam como uma espécie de blindagem à influência política, faz recair sobre seus atos decisórios um déficit democrático, uma vez que nem mesmo o chefe do Poder Executivo eleito pelo voto tem qualquer tipo de controle sobre referidas entidades.

Por força constitucional toda a administração pública, direta ou indireta, deve ser dialógica e promover a participação social em seus processos de tomada de decisão, notadamente naquilo que repercutir na vida dos cidadãos. Essa necessidade de oitiva da população, posta como condição de legitimidade dos atos

\footnotetext{
74 MASTRANGELO, Cláudio. Agências reguladoras e participação popular. Porto Alegre: livraria do Advogado, 2005, p. 20.

75 OLIVEIRA, Fabiano Viana; PEREIRA, Aliger dos Santos. A Noção de Cidadania em Chantal Mouffe, Dentro do Debate Entre Liberais e Comunitaristas. Revista Argumento, no 8. Ano VI, ISSN 11063616, Salvador: FFCH/Ufba, 2007, p. 10.
} 
CADEMARTORI, Daniela Mesquita Leutchuk de; CAMPOS, Luciana Oliveira. Democracia e participação social efetiva: confrontação agonística como instrumento de legitimação dos atos das Agências Reguladoras brasileiras. Revista Eletrônica Direito e Política, Programa de Pós-Graduação Stricto Sensu em Ciência Jurídica da UNIVALI, Itajaí, v.13, n.3, $3^{\circ}$ quadrimestre de 2018. Disponível em: www.univali.br/direitoepolitica - ISSN 1980-7791

administrativos, tem ainda mais força quando se trata das Agências Reguladoras porque além da obrigação constitucional, há a necessidade de superar as carências democráticas decorrentes de sua autonomia perante o poder eleito.

A realização de audiências e consultas públicas previamente a tomadas de decisões é instrumento de uso corrente por parte de Agências Reguladoras. Contudo, os processos de participação social não podem ser considerados efetivos, e consequentemente não possuem a capacidade de legitimação, quando são realizados meros procedimentos formais de abertura de espaço para participação e as diferentes identidades que compõem a complexidade de nossa sociedade não dispõem de condições reais de participar e se fazer ouvir.

A democracia plural radical na forma proposta por Chantal Mouffe se mostra como um instrumento interessante de participação social em que se fazem necessárias instituições promotoras de conflito cujos princípios básicos da relação agonística estejam pré-estabelecidos, possibilitando a que diferentes e conflitantes identidades atuem de forma efetiva e construam hegemonias contigentes com base em equivalências e diferenças a partir do outro que diverge, visto como mero oponente e não como inimigo.

Se as Agências Reguladoras conseguirem atuar como instituições promotoras dessa confrontação agonística, e a partir do exercício de articulação, obtiverem hegemonias contingentes, estarão em conformidade com o Estado Democrático de direito podendo-se aventar a ideia de que tenha sido superado qualquer déficit democrático que recaia sobre estas.

\section{REFERÊNCIA DAS FONTES CITADAS}

AGUILLAR, Fernando Herren. Controle social de serviços públicos. São Paulo: Max Limonad, 1999.

ALVES, Ana Rodrigues Cavalcanti. O conceito de hegemonia: de Gramsci a Laclau e Mouffe. Lua Nova. São Paulo, n. 80, p. 71-96, 2010. Disponível em: <http://www.scielo.br/pdf/In/n80/04.pdf>. Acesso em 21. Set. 2018

ARAGÃO, Alexandre Santos de. Agências reguladoras e a evolução do direito administrativo econômico. 3. ed. Rio de Janeiro: Forense, 2013. 
CADEMARTORI, Daniela Mesquita Leutchuk de; CAMPOS, Luciana Oliveira. Democracia e participação social efetiva: confrontação agonística como instrumento de legitimação dos atos das Agências Reguladoras brasileiras. Revista Eletrônica Direito e Política, Programa de Pós-Graduação Stricto Sensu em Ciência Jurídica da UNIVALI, Itajaí, v.13, n.3, $3^{\circ}$ quadrimestre de 2018. Disponível em: www.univali.br/direitoepolitica - ISSN 1980-7791

ATIENZA, Manuel. As razões do direito. Teorias da argumentação jurídica. Tradução de Maria Cristina Guimarães Cupertino. 3.ed. São Paulo: Landy, 2003.

BARDIN, Lawrence. Análise de conteúdo. Tradução de Luís Antero Reto e Augusto Pinheiro. São Paulo: Ed. 70, 2011.

BARROSO, Luís Roberto. Agências reguladoras. Constituição, Transformações do Estado e legitimidade democrática. Revista de Direito da Procuradoria Geral, Rio de Janeiro, n. 56, 2002. Disponível em: <http://www.rj.gov.br/web/pge/exibeConteudo?article-id=780277>. Acesso em 20 set. 2018.

BINENBOJM, Gustavo. Uma teoria do direito administrativo: direitos fundamentais, democracia e constitucionalidade. Rio de Janeiro: Renovar, 2014.

BOBBIO, Norberto. O Futuro da Democracia. Uma defesa das regras do jogo. Tradução de M. A. Nogueira. Rio de Janeiro: Paz e Terra, 1986.

BOURDIEU, Pierre. Contrafogos 2: por um movimento social europeu. Tradução de André Telles. Rio de Janeiro: Jorge Zahar, 2001.

Contrafogos 1: táticas para enfrentar a invasão neoliberal. Tradução de Lucy Magalhães. Rio de Janeiro: Jorge Zahar, 1998.

O poder simbólico. Tradução de Fernando Tomaz. 9. ed. Rio de Janeiro: Bertrand Brasil, 2006.

BRASIL. Agência Nacional de Energia Elétrica - ANEEL. Audiência Pública no 06/2015. Brasília, 2015a. Disponível em: <http://www.aneel.gov.br/aplicacoes/audiencia/dspListaAudiencia.cfm? attAnoAud=2015\&attAnoFasAud=2015\&id_area=13>. Acesso em: 21 set. 2018

CADEMARTORI, D. M. L. de; STAFFEN, M. R. A Função democrática do princípio do contraditório no processo administrativo disciplinar. Revista Direitos Fundamentais \& Justiça. PUC/RS, Porto Alegre, v. 12, s. 12, p. 235-246, 2010.

CAÉLLAR, Leila. As agências reguladoras e seu poder normativo. São Paulo: Dialética, 2001.

CAMPOS, Luciana Oliveira de. Setor Elétrico: Regulação e as audiências públicas promovidas pela ANEEL. Rio de Janeiro: Lumen Juris, 2018.

DI PIETRO, Maria Sylvia Zanella. Parcerias na administração pública: concessão, permissão, franquia, terceirização e outras formas. 3. ed. São Paulo: Atlas, 1999.

FARIA, José Eduardo (Org.). Direito e globalização econômica: implicações e perspectivas. São Paulo: Malheiros, 1998.

HABERMAS, Jürgen. Direito e democracia: entre facticidade e validade. 2.ed. Tradução de Flavio Beno Siebeneichler. Rio de Janeiro: Tempo Brasileiro, 2003, v.I 
CADEMARTORI, Daniela Mesquita Leutchuk de; CAMPOS, Luciana Oliveira. Democracia e participação social efetiva: confrontação agonística como instrumento de legitimação dos atos das Agências Reguladoras brasileiras. Revista Eletrônica Direito e Política, Programa de Pós-Graduação Stricto Sensu em Ciência Jurídica da UNIVALI, Itajaí, v.13, n.3, $3^{\circ}$ quadrimestre de 2018. Disponível em: www.univali.br/direitoepolitica - ISSN 1980-7791

Direito e moral (Tanner Lectures, 1986). In:

Direito e democracia: entre facticidade e validade. Tradução de Flavio Beno Siebeneichler. 2.ed. Rio de Janeiro: Tempo Brasileiro, 2003, v. II, p. 193-248, Título original: Faktizität und Geltung.

Para uma reconstrução do direito (I): o sistema dos direitos. In:

Direito e democracia: entre facticidade e validade. Tradução de Flavio Beno Siebeneichler. 2.ed. Rio de Janeiro: Tempo Brasileiro, 2003, v. I. Título original: Faktizität und Geltung.

Política deliberativa: um conceito procedimental de democracia. In:

Direito e democracia: entre facticidade e validade. Tradução de Flavio Beno Siebeneichler. 2.ed. Rio de Janeiro: Tempo Brasileiro, 2003, v. II, p. 9-56, Título original: Faktizität und Geltung.

Três modelos normativos de democracia. Tradução de Anderson Fortes Almeida e Acir Pimenta Madeira. Cadernos da Escola do Legislativo. Belo Horizonte, n. 3, p. 107-121, jan./jun. 1995.

. O estado nação europeu frente os desafios da globalização. Revista Novos Estudos. São Paulo, n. 43, p. 65-110, nov. 1995.

GUIMARÃES, Lucas Noura de Moraes. Regulação da exploração da eletricidade: compatibilidade com as leis da natureza e com a ordem econômica constitucional. Curitiba: CRV, 2013.

KOZICKI, Katya. Prefácio In: MOUFFE, Chantal. Sobre o Político. Tradução de Fernando Santos. São Paulo: Martins Fontes, 2015.

LACLAU, Ernesto; MOUFFE, Chantal. Hegemonia e Estratégia Socialista: por uma política democrática radical. Tradução de Joanildo A. Burity et al. São Paulo: Intermeios, 2015.

LEHFELD, Lucas de Souza. Controles das agências reguladoras. São Paulo: Atlas, 2008.

LOPES, Alice Casimiro; MENDONÇA, Daniel de; BURITY, Joanildo A. A Contribuição de Hegemonia e estratégia socialista para as ciências humanas e sociais. In LACLAU, Ernesto; MOUFFE, Chantal. Hegemonia e Estratégia Socialista: por uma política democrática radical. Tradução de Joanildo A. Burity et al. São Paulo: Intermeios, 2015.

MASTRANGELO, Cláudio. Agências reguladoras e participação popular. Porto Alegre: Livraria do Advogado, 2005.

MENDONÇA, Daniel de. Teorizando o agonismo: crítica a um modelo incompleto. Revista Sociedade e Estado. Departamento de Sociologia da UnB, Brasília, v. 25, n.3, p. 479-497, set./dez. 2010. Disponível em: http://www.scielo.br/pdf/se/v25n3/04.pdf Acesso em: 21 set. 2018. 
CADEMARTORI, Daniela Mesquita Leutchuk de; CAMPOS, Luciana Oliveira. Democracia e participação social efetiva: confrontação agonística como instrumento de legitimação dos atos das Agências Reguladoras brasileiras. Revista Eletrônica Direito e Política, Programa de Pós-Graduação Stricto Sensu em Ciência Jurídica da UNIVALI, Itajaí, v.13, n.3, $3^{\circ}$ quadrimestre de 2018. Disponível em: www.univali.br/direitoepolitica - ISSN 1980-7791

MOTTA, Paulo Roberto Ferreira. Agências reguladoras. Barueri: Manole, 2003.

MOREIRA, Egon Bockmann; SOARES JÚNIOR, Lauro Antônio Nogueira. Regulação econômica e democracia: a questão das agências administrativas independentes. In: BINENBOJM, Gustavo (or.). Agências reguladoras e democracia. Rio de Janeiro: Lumen Juris, 2006.

MOUFFE, Chantal. Democracia, cidadania e a questão do pluralismo. Tradução de K. Prudencio. Política \& Sociedade. UFSC, Florianópolis, v. 2, no 3, p. 11-26, $2003 . \quad$ Disponível em: <https://periodicos.ufsc.br/index.php/politica/article/view/2015>. Acesso em: 21 set. 2018.

. Por um modelo agonístico de democracia. Tradução de P. S. Ghetti. Revista de Sociologia Política. UFPR, Curitiba, n. 5, p. 11-23, nov. 2005. Disponível em: <http://www.scielo.br/pdf/rsocp/n25/31108.pdf>. Acesso em: 21 set. 2018.

Fontes, 2015

Sobre o Político. Tradução de Fernando Santos. São Paulo: Martins

NUNES, Dierle José Coelho. Direito constitucional ao recurso: da teoria geral dos recursos, das reformas processuais e da comparticipação das decisões. Rio de Janeiro: Lúmen Juris, 2006.

OLIVEIRA, Francisco Mesquita de. Ações Coletivas, Cultura Política e Movimentos Sociais: disputas de significado e antagonismo no âmbito da reforma urbana. Tese (Doutorado em Sociologia). Programa de Pós-Graduação em Sociologia. Universidade Federal de Pernambuco. Recife, 2010. Disponível em: <http://repositorio.ufpe.br/handle/123456789/9274>. Acesso em: 21 set. 2018.

OLIVEIRA, Marcelo Antonio Cattoni de. Direito processual constitucional. Belo Horizonte: Mandamentos, 2001.

OLIVEIRA, Fabiano Viana; PEREIRA, Aliger dos Santos. A Noção de Cidadania em Chantal Mouffe, Dentro do Debate Entre Liberais e Comunitaristas. Revista Argumento, no 8. Ano VI, ISSN 1106-3616, Salvador: FFCH/Ufba, 2007.

ROSA, Alexandre Morais da. Decisão penal: bricolage de significantes. Rio de Janeiro: Lúmen Juris, 2006.

SANTOS, Boaventura de Sousa. A Difícil democracia. Reinventar as esquerdas. São Paulo: Boitempo, 2016.

SCHNEIDER, Yuri. Agências reguladoras e democracia: a necessária aplicação do modelo de democracia cooperativa reflexiva do conhecimento para legitimação de sua atuação. 2013, 250f. Tese (Doutorado em Direito). Programa de PósGraduação em Direito. Universidade do Vale do Rio dos Sinos. São Leopoldo, 2013. Disponível em: <http://www.repositorio.jesuita.org.br/bitstream/handle/UNISINOS/4227/Yuri+S 
CADEMARTORI, Daniela Mesquita Leutchuk de; CAMPOS, Luciana Oliveira. Democracia e participação social efetiva: confrontação agonística como instrumento de legitimação dos atos das Agências Reguladoras brasileiras. Revista Eletrônica Direito e Política, Programa de Pós-Graduação Stricto Sensu em Ciência Jurídica da UNIVALI, Itajaí, v.13, n.3, $3^{\circ}$ quadrimestre de 2018. Disponível em: www.univali.br/direitoepolitica - ISSN 1980-7791

chneider.pdf; jsessionid=EFE31497861AB0BE644A7F7CFFD1B896 ? sequence $=1>$. Acesso em: 23 set. 2018.

VERGARA ESTÉVEZ, Jorge. La utopía neoliberal y sus críticos. Utopìa y Praxis Latinoamericana, Venezuela, v. 10, n. 31, p. 37-62, Oct./Dic. 2005. Disponível em: <http://www.redalyc.org/pdf/279/27903103.pdf>. Acesso em: 22 set. 2018.

Recebido em: 24/09/2018

Aprovado em: 16/10/2018 